\title{
CYD-TDV Dengue Vaccine: Systematic Review and Meta-Analysis of Efficacy, Immunogenicity and Safety
}

Isabella Piassi Godói ${ }^{1,2}$, Livia Lovato Pires Lemos², Vânia Eloisa de Araújo³, Braúlio Cesar Bonoto', ${ }^{*}$ Brian Godman ${ }^{4,5}$, Augusto Afonso Guerra Júnior ${ }^{1,2}$

${ }^{1}$ Programa de Pós-graduação em Medicamentos e Assistência Farmacêutica, sala 1023, Faculdade de Farmácia, Universidade Federal de Minas Gerais, Av. Presidente Antônio Carlos, 6627, Campus Pampulha, Belo Horizonte, Minas Gerais, CEP 31270-901, Brazil. Emails: Email: isabellapiassi@gmail.com; brauliofarma@yahoo.com.br; augustoguerramg@gmail.com 2SUS Collaborating Centre for Technology Assessment and Excellence in Health, sala 1042, Faculdade de Farmácia, Universidade Federal de Minas Gerais, Av. Presidente Antônio Carlos, 6627, Campus Pampulha, Belo Horizonte, Minas Gerais, CEP 31270-901, Brazil. Email: lilolemos@gmail.com

${ }^{3}$ Faculdade de Odontologia, Instituto de Ciências Biológicas e da Saúde, Pontifícia Universidade Católica de Minas Gerais, Av. Dom José Gaspar, 500 Coração Eucaristíco, Belo Horizonte, Minas Gerais, CEP 30535-901, Brazil. Email: vaniaearaujo@gmail.com

${ }^{4}$ Institute of Pharmacy and Biomedical Sciences. 161 Cathedral Street, Glasgow G4 ORE, United Kingdom. Email: Brian.godman@strath.ac.uk

${ }^{5}$ Division of Clinical Pharmaclogy, Karolinska Institutet, Karolinska University Hospital, SE-141 86, Stockholm, Sweden. Email: Brian.Godman@ki.se

*Author for correspondence. Division of Clinical Pharmacology, Karolinska Institute, Karolinska University Hospital Huddinge, SE-141 86, Stockholm, Sweden. Email: Brian.Godman@ki.se. Telephone + 46858581068 . Fax + 46859581070 and Strathclyde Institute of Pharmacy and Biomedical Sciences, University of Strathclyde, Glasgow G4 ORE, United Kingdom. Email: brian.godman@strath.ac.uk.Telephone: 0141

(Accepted for publication Journal of Comparative Effectiveness Research)

\section{Abstract}

Introduction: Dengue virus is a serious global health problem. CYD-TDC (Dengvaxia $®$ ) was the first vaccine to gain regulatory approval to try and address this problem. Aim: Summarize all available evidence on the immunogenicity, efficacy and safety of the CYD-TDV vaccine. Method: Meta analysis and systematic review. Results: The best and worst immunogenicity results were for DENV4 and DENV1, respectively. Vaccine efficacy of $60 \%$ was derived from studies with participants aged 2-16 years old, with DENV4 and DENV2 presenting the best and worst results, respectively. Erythema and swelling were more frequent with CYD-TDV. No differences were detected for systemic adverse events. Conclusion: CYD-TDV showed moderate efficacy in children and adolescents. From the immunogenicity results in adults, we can expect satisfactory efficacy from vaccination in this population.

Keywords: Dengue; meta-analysis; systematic review; vaccines; CYD-TDV

\section{Introduction}

Dengue is a mosquito-borne virus disease considered a serious global health problem with an estimated 390 million dengue infections per year [1]. Most dengue virus infections are asymptomatic, and clinical manifestations range from mild fever to severe life-threatening disease [2-6]. Dengue virus (DENV) belongs to the genus Flavivirus of the Flaviviridae family [3, 4], and has four DENV serotypes (DENV1-4) with distinct phylogenetic and antigenic characteristics $[3,4,7,9]$.

Dengue is rapidly expanding and has a global footprint, representing a public health challenge with an appreciable economic burden. Trade globalization and rapid urbanization in Asia and Latin 
America, and the abundance of vector breeding sites within crowded urban communities, have contributed to the endemicity observed in these regions $[3,4,10]$. It is estimated that in 2013 there were a total of 58.40 million symptomatic dengue virus infections, including more than 13500 fatal cases [11]. For 2015, it was estimated that over 3.9 billion people lived at risk for infection worldwide [2]. The annual costs of dengue have ranged from US\$13.5million in Nicaragua to US $\$ 56$ million in Malaysia (in 2010 values) up to 2013. [12]. Considering 141 countries and territories with active dengue transmission, the total annual global cost of dengue illness were estimated at US $\$ 8.9$ billion in 2013 [11].

The development of an effective vaccine against the four DENV serotypes represents an important strategy for the control of the disease $[13,14]$. The vaccines for monotype Flavivirus, such as Yellow Fever, Japanese encephalitis, have a 95\% efficacy and were used as an inspiration for the development of a dengue vaccine $[15,16]$. Since the 1970s, several techniques have been applied to provide a vaccine capable of inducing immunity to the four virus serotypes [11]. Several vaccine candidates have been developed using live attenuated viruses, inactivated viruses and DNA vaccines [13,14,17-33]. The chimeric tetravalent vaccine (CYD-TDV) of Sanofi Pasteur, Dengvaxia ${ }^{\circledR}$, was the first vaccine to be licensed. By October 2016, eleven countries had granted regulatory approval for Dengvaxia ${ }^{\circledR}$, e.g. Mexico, the Philippines, Brazil, El Salvador, Costa Rica, Paraguay, Guatemala, Peru, Indonesia, Thailand and Singapore [34-38]. Vaccination is indicated for individuals living in endemic regions aged between 9 and 45 years old, with the exception of Paraguay which extended the upper limit to people of 60 years old [39].

The capacity of a vaccine to generate an immune response may be influenced by many factors including age, presence of underlying disease, immune status and previous exposure to the same or similar substances (seropositivity). It is likely that in endemic settings, pre-sensitization may cause an immune response before vaccination [40], which may have been the case with CYD-TDV. In phase III trials vaccination showed lower efficacy in seronegative individuals, suggesting that the vaccine broadens pre-existing immunity rather than efficiently raises new protective immunity [ 41 , 42].

The lower age limit of nine years old for CYD-TDV vaccination is explained by the results from the age stratified analysis of the two available multicentric double-blind randomized controlled trials conducted with subjects between 2 and 16 years old [30,31]. More importantly, long-term safety analysis revealed a higher risk of hospitalization due to dengue in patients vaccinated between 2 and 5 years old [43]. Up to now, there has been no published phase III trial with adults, and the indication for adult vaccination is probably derived from immunogenicity results.

In this context, it was demonstrated that with a routine CYD-TDV vaccination programme in endemic countries at 9 years of age, a reduction of 10 to $30 \%$ in symptomatic and hospitalized dengue illness is expected over the next 30 years [41, 44]. In addition, Ferguson et al (2016) developed a model that considering routine vaccination at $80 \%$ coverage of individuals between 2 and 18 years old, there was an expected reduction of 20 to $30 \%$ in both symptomatic disease and hospitalization in high-transmission settings [45]. Both models predicted that as transmission intensity increased, the optimal age for routine vaccination decreased $[44,45]$.

The purposes of this systematic review with meta-analysis were to access efficacy and safety of CYD-TDV and for the first time explore its immunogenicity results, as to better understand the indication of the vaccine to this age group. As a result, help governments with their ongoing deliberations regarding the utilization and funding of such vaccines.

\section{Methods}

We conducted a systematic review with meta-analysis following principles described in the Cochrane Handbook [46]. The manuscript was prepared using the Preferred Reporting Items for Systematic Reviews and Meta-Analysis (PRISMA) [47]. 


\section{Eligibility criteria}

We considered for inclusion all phase II and III randomized clinical trials of Sanofi Pasteur's tetravalent dengue vaccine (CYD-TDV) as well as a control group including placebo or other vaccines, e.g. pneumococcal polysaccharide or meningococcal polysaccharide, or a combination of these. We considered studies assessing safety, immunogenicity and efficacy of the vaccine in children, adolescents and adults. We excluded phase I trials and studies that had not reported outcomes of interest. Our population of interest involved individuals in dengue endemic regions independents of age (i.e. children, adolescent and adult). We also excluded phase Ilb in this analysis due to the differences between the populations involved in the phase IIb and III trials making the analysis difficult.

\section{Study search}

Article searches were performed in the Cochrane Controlled Trials Register, PUBMED and LILACS (March/2016). Various combinations of terms were used to search these electronic databases, including terms referring to the disease, interventions, and types of studies. The complete search strategies are provided as Supplementary Material (Search Strategy).

We also searched for trials at ClinicalTrials.gov. Ongoing trials were assessed for eligibility, and studies described as completed were manually searched (when not captured by the initial search strategy). A gray literature search was also performed at ProQuest Dissertation \& Theses

Database. In addition, considering the importance of dengue in Brazil, we used the following theses and dissertations databases in Brazil: Brazilian Digital Library of Theses and Dissertations, the Digital Library of Theses and Dissertations of USP (University of São Paulo) and of UFMG.

\section{Study selection and data collection processes}

Two independent reviewers (IPG, BCB) performed the selection of potential papers in three phases, i.e. the analyses of titles, abstracts, and whole texts. A third reviewer (LLPL) analyzed any dissimilar results to resolve any differences. Three independent researchers collected the data (IPG, BCB, LLPL). When reports mentioned the existence of supplementary material or appendix, they were consulted for data collection.

\section{Outcome measures}

For immunogenicity, we considered the geometric mean titers (GMTs) of neutralizing antibodies against each dengue serotype 28 days after the last dose of vaccination. In this test, the sera were tested by plaque reduction neutralization test (PRNT), a geometric interpretation of the titers of selected human sera against DENV (1-4) [48]. As a result, the participants with PRNT50 >10 against one or more serotypes were considered seropositive. For efficacy measures, we considered the number of virologically confirmed dengue cases and the number of person-years of follow-up in each group. For this evaluation, blood samples were taken from all participants at month 13 (28 days after the third dose), per protocol analysis. The intention-to treat efficacy population included volunteers who receive $\geq 1$ dose, and the efficacy against each serotype was determined by episodes occurring from month 13 to month 25 in the modified per-protocol population, i.e. participants who had received all three doses [30,31]. For adverse events and safety measures, we considered the following: Injection site reactions (0-7 days after first dose) (pain, erythema and swelling); systemic safety parameters in any grade (fever, headache, malaise, myalgia, arthralgia); Serious Adverse Events (SAE) were collected until 21 or 28 days after each vaccination scheme. A risk ratio lower than 1.0 demonstrated better results for CYD-TDV.

\section{Statistical analysis}

We used the Review Manager@ 5.3 software to pool data using a random effects meta-analysis model. Analyses with an $\mathrm{I}^{2}>40 \%$ and $\mathrm{P}$ value for the $\mathrm{X}^{2}$ test $<0.10$ [49] were considered to have substantial heterogeneity. We presented the risk ratio (dichotomous) and the mean difference (continuous) with a 95\% confidence interval as association measures and the results of $\mathrm{I}^{2}$ and $\mathrm{p}$ - 
value of the heterogeneity test. Subgroup analysis was performed to evaluate the immunogenicity and safety results according to geographic region (Supplementary Material - Table S2).

Quality of evidence and risk of bias

We assessed the risk of bias of the clinical trials using the Cochrane Collaboration methodology. We judged the possible bias in three levels - high risk, low risk and unclear (when the provided information was not sufficient to make a clear judgment). We considered the following possible bias: Random sequence generation and allocation concealment (selection bias); blinding of participants and personnel (performance bias); blinding of outcome assessment (detection bias); and selective reporting (reporting bias) [50]. For studies with laboratory measures or efficacy as an outcome, blinding of participants and personnel was considered of minor importance. In these cases, the trials were judged as presenting a low risk of bias for performance bias. Since safety assessments typically include subjective outcomes such as pain and myalgia, blinding of participants and personnel was considered of high importance. If the same study reported laboratory/efficacy and safety outcomes and the participants were not blinded, the judgment was a high risk for performance bias.

\section{Results}

\section{Study inclusion}

Of the 895 titles screened, the abstracts of 321 records were assessed, and among these, 89 fulltext studies were assessed for eligibility. Six phase II [23-28] and three phase III randomized clinical trials [29-31] were included. Figure 1 provides details of how the final 9 studies were derived. From the search at ClinicalTrials.gov, we included one ongoing trial in phase II trials for CYD-TDV (Figure 1). 
Figure 1 - Study Flow

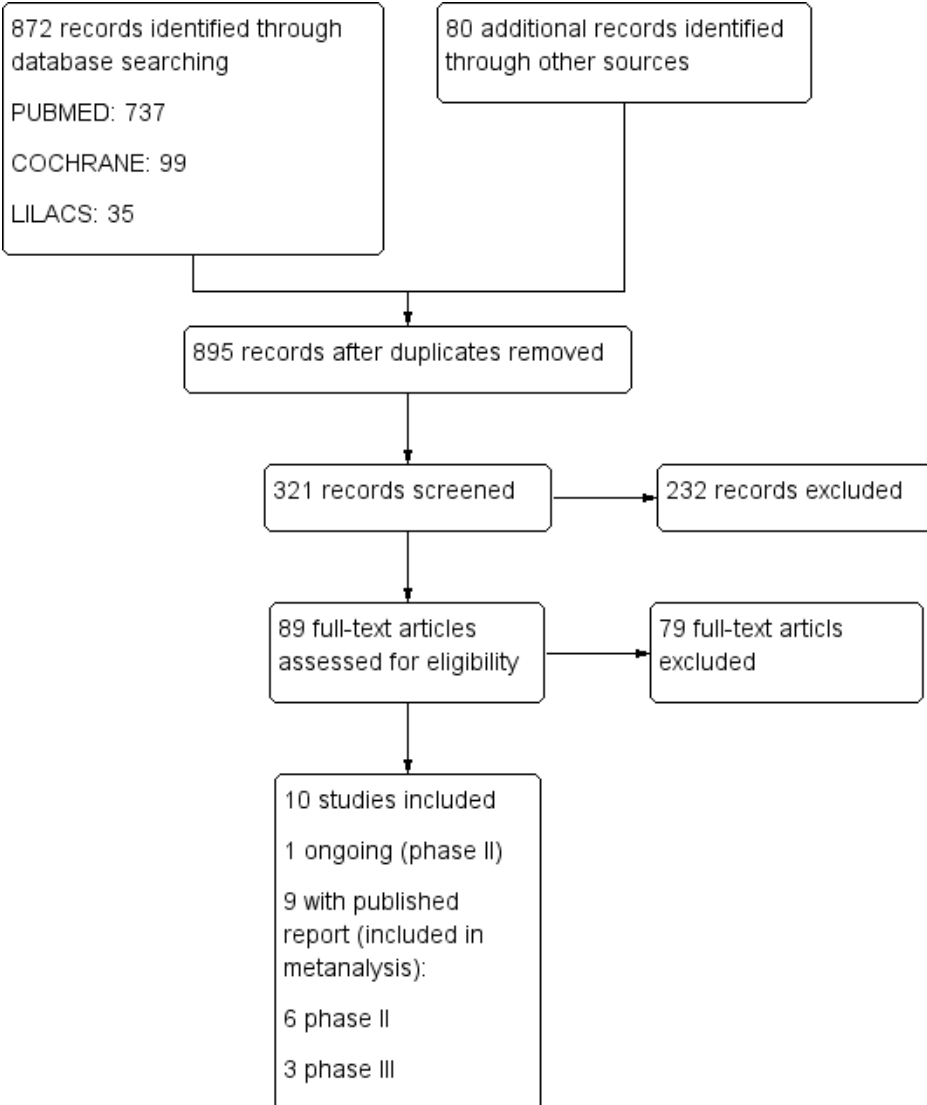

Characteristics of the studies

Three phase III trials evaluated CYD-TDV [29-31]. All included studies were conducted in endemic areas of Latin America [23, 25, 28, 21] or Southeast Asia [24, 26, 27, 29, 30] (Table 1). A total of 34,631 volunteers participated in CYD-TDV phase II-III trials (CYD-TDV, $n=23,193$; control, $n=$ 11,438). The trials applied a 2:1 [23-25,27,28,30,31], 3:1 [26] and a 4: 1 [29] randomization ratio. Vaccine schedule was three doses with 6-months interval. The control groups of the phase II trials were composed of a combination of placebo (one or two doses) and another vaccine (e.g. pneumococcal polysaccharide, meningococcal polysaccharide) (one or two doses).

All phase III studies were placebo controlled. As a group, the phase II trials evaluated children adolescents and adults ( 2 to 45 years old), whereas phase III trials were conducted only with children and adolescents (2 to 17 years old) (Table 1). Six percent of participants did not complete the CYD-TDV vaccination schedule in the phase II trials [23-28]. Two phase III trial reported losses to follow-up ( $0.8 \%$ in the CYD-TDV) [29, 30]. The main reason for the losses to follow-up was voluntary withdrawal not due to an adverse event (Supplementary Material - Table S1). This vaccine was approved for individuals between 9 to 45 years old and 9 to 60 years old [39]. 
Table 1 - Description of the characteristics of the included studies

\begin{tabular}{|c|c|c|c|c|c|c|c|c|}
\hline Study & $\begin{array}{c}\text { Desig } \\
\text { n }\end{array}$ & $\begin{array}{c}\text { Age } \\
\text { Range } \\
\text { (years) }\end{array}$ & Country & $\begin{array}{c}\text { Duratio } \\
n \\
\text { (months } \\
\text { ) }\end{array}$ & Groups & $\mathbf{N}$ & $\begin{array}{c}\text { Age } \\
(\text { years }(\mathrm{SD}))\end{array}$ & $\begin{array}{c}\text { Male } \\
(\mathbf{N}(\%))\end{array}$ \\
\hline Daylan et al. (2013) & II & $9-16$ & Brazil & 13 & CYD-TDV & 100 & $12.7(2.1)$ & $40(40)$ \\
\hline$[23]^{\mathrm{A}}$ & & & & & Placebo & 50 & $12.7(2.1)$ & $28(55)$ \\
\hline \multirow[t]{2}{*}{$\begin{array}{l}\text { Sabchareon et al. } \\
(2012)[24]^{C}\end{array}$} & II B & $4-11$ & Thailand & 12 & CYD-TDV & 2,452 & $8.26(2.0)$ & $\begin{array}{c}1,187 \\
(48)\end{array}$ \\
\hline & & & & & $\begin{array}{l}\text { Placebo }+ \text { rabies } \\
\text { vaccine }\end{array}$ & 1,221 & $8.23(2.1)$ & $583(48)$ \\
\hline \multirow{2}{*}{$\begin{array}{l}\text { Villar et al. (2013) } \\
{[25]^{\mathrm{A}}}\end{array}$} & II & $9-16$ & Colombia, & 13 & CYD-TDV & 401 & 12.6 (NR) & $197(49)$ \\
\hline & & & $\begin{array}{c}\text { Mexico, } \\
\text { Puerto } \\
\text { Rico }\end{array}$ & & $\begin{array}{l}\text { Placebo }+ \text { (tetanus }+ \\
\text { diphtheria }+ \text { acelular } \\
\text { pertusis })\end{array}$ & 199 & $12.5(\mathrm{NR})$ & $91(46)$ \\
\hline \multirow{2}{*}{$\begin{array}{l}\text { Leo et al. (2012) } \\
{[26]^{\mathrm{B}}}\end{array}$} & II & $2-45$ & Singapore & 18 & CYD-TDV & 438 & $17.8(10.9)$ & $193(44)$ \\
\hline & & & & & Placebo + Hepatite A & 147 & $18.2(11.2)$ & $80(54)$ \\
\hline \multirow{2}{*}{$\begin{array}{l}\text { Tran et al. (2012) } \\
{[27]^{\mathrm{A}}}\end{array}$} & II & $2-45$ & Vietnam & 18 & CYD-TDV & 120 & - & $58(48)$ \\
\hline & & & & & $\begin{array}{l}\text { Menomune A + } \\
\text { placebo + Typhim } \\
\text { virus }\end{array}$ & 60 & - & $35(58)$ \\
\hline \multirow{6}{*}{$\begin{array}{l}\text { Lanata et al. (2012) } \\
{[28]^{\mathrm{A}}}\end{array}$} & II & $2-11$ & Peru & 12 & CYD-TDV (2-5 yr) & 100 & $3.9(1.1)$ & $55(55)$ \\
\hline & & & & & Placebo + & & $3.9(1.2)$ & \\
\hline & & & & & $\begin{array}{l}\text { Pneumococcal } \\
\text { polysaccharide }(2-5 \mathrm{yr})\end{array}$ & 50 & & $25(50)$ \\
\hline & & & & & CYD-TDV (6-11 yr) & 99 & $8.8(1.9)$ & $46(46)$ \\
\hline & & & & & Placebo + & & $8.8(1.8)$ & \\
\hline & & & & & $\begin{array}{l}\text { Pneumococcal } \\
\text { polysaccharide (6-11 } \\
\text { yr) }\end{array}$ & 49 & & $21(43)$ \\
\hline \multirow{2}{*}{$\begin{array}{l}\text { Amar-Singh et al. } \\
(2013)[29]^{\mathrm{D}}\end{array}$} & III & $2-11$ & Malaysia & 18 & CYD-TDV & 199 & $6.4(2.8)$ & $96(48)$ \\
\hline & & & & & Placebo & 51 & $6.5(3.0)$ & $32(63)$ \\
\hline \multirow[t]{2}{*}{$\begin{array}{l}\text { Capeding et al. } \\
(2014)[30]^{\mathrm{C}}\end{array}$} & III & $2-14$ & $\begin{array}{l}\text { Indonesia, } \\
\text { Malaysia, }\end{array}$ & 25 & CYD-TDV & 6,710 & $8.8(3.4)$ & $\begin{array}{c}3,253 \\
(48)\end{array}$ \\
\hline & & & $\begin{array}{c}\text { Philippines } \\
\text { Thailand, } \\
\text { Vietnam }\end{array}$ & & Placebo & 3,350 & $8.8(3.4)$ & $\begin{array}{c}1,623 \\
(48)\end{array}$ \\
\hline \multirow[t]{2}{*}{$\begin{array}{l}\text { Villar et al. (2015) } \\
{[31]^{\mathrm{C}}}\end{array}$} & III & $9-16$ & $\begin{array}{l}\text { Brazil, } \\
\text { Colombia, }\end{array}$ & 25 & CYD-TDV & 12,574 & $12.4(2.1)$ & $\begin{array}{c}6,254 \\
(50)\end{array}$ \\
\hline & & & $\begin{array}{l}\text { Mexico, } \\
\text { Honduras, } \\
\text { Puerto } \\
\text { Rico }\end{array}$ & & Placebo & 6,261 & $12.4(2.1)$ & $\begin{array}{c}3,105 \\
(50)\end{array}$ \\
\hline
\end{tabular}

${ }^{\text {A }}$ Population described: Participants that vaccinated with at least the first dose; ${ }^{\mathrm{B}}$ Population described: Immunogenicity analysis set; ${ }^{\mathrm{C}}$ Population described: Per-protocol analysis for efficacy; ${ }^{\mathrm{D}}$ Population described: Safety analysis set. SD: Standard Deviation 
There is one study ongoing phase II randomised control trial (NCT01943305) that evaluates CYD and is being conducted in Singapore with 90 volunteers (18-45 ages), expected to be completed by the end of 2016. This study is being funded by Sanofi Pasteur and the Medical School of Singapore, with the Singapore General Hospital collaborating.

Methodological quality and risk of bias

All trials presented low risk of bias for important aspects, such as random sequence generation, allocation concealment and selective reporting The losses to follow-up of the included trials were few and balanced between vaccine and control arms, resulting in low risk of attrition bias in most studies. In one trial, the reasons participants did not complete as per the protocol vaccination schedule was not completely reported, resulting in unclear risk for attrition bias [26] (Figure 2).

Figure 2 - Risk of bias analysis - Review of authors' judgments about each risk of bias presented as percentages across all included studies

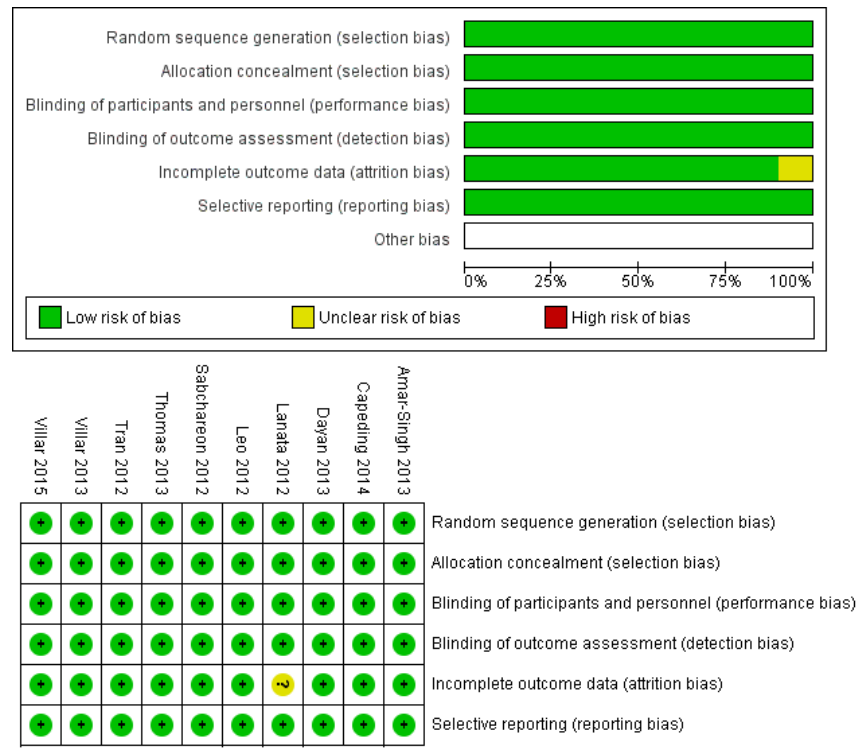

Immunogenicity

All meta-analysis results favored CYD for both children and adolescents (2-16 years old) [21, 23, $25,26,28,29]$ and adults [26, 27]. The best results for serotype-specific immune response 28 days after the last dose of CYD or control in both groups were for DENV4 (children and adolescents, $\mathrm{MD}=0.84 ; 95 \% \mathrm{Cl} 0.73,0.95 ; \mathrm{I}^{2}=0 \% ; \mathrm{p}=0.71$; adults, $\mathrm{MD}=0.77 ; 95 \% \mathrm{Cl} 0.60,0.93 ; \mathrm{I}^{2}=0 \% ; \mathrm{p}=0.97$ ) and DENV-3 (children and adolescents, $\mathrm{MD}=0.67 ; 95 \% \mathrm{Cl} 0.55,0.79 ; \mathrm{I}^{2}=9 \% ; \mathrm{p}=0.36$; and adults, $\left.\mathrm{MD}=0.72 ; 95 \% \mathrm{Cl} 0.56,0.89 ; \mathrm{I}^{2}=0 \% ; \mathrm{p}=0.96\right)$. DENV1 was the worst result for children and adolescents $\left(\mathrm{MD}=0.41 ; 95 \% \mathrm{Cl} 0.23,0.58 ; \mathrm{I}^{2}=58 \% ; \mathrm{p}=0.03\right)$ and adults $(\mathrm{MD}=0.46 ; 95 \% \mathrm{Cl} 0.30$, $\left.0.63 ; l^{2}=0 \% ; p=0.79\right)$. The immunogenicity was presented in figure $3 \mathrm{~A}$ (children and adolescent) and 3B (adults). 
Figure 3A - Immunogenicity of CYD for children/adolescents

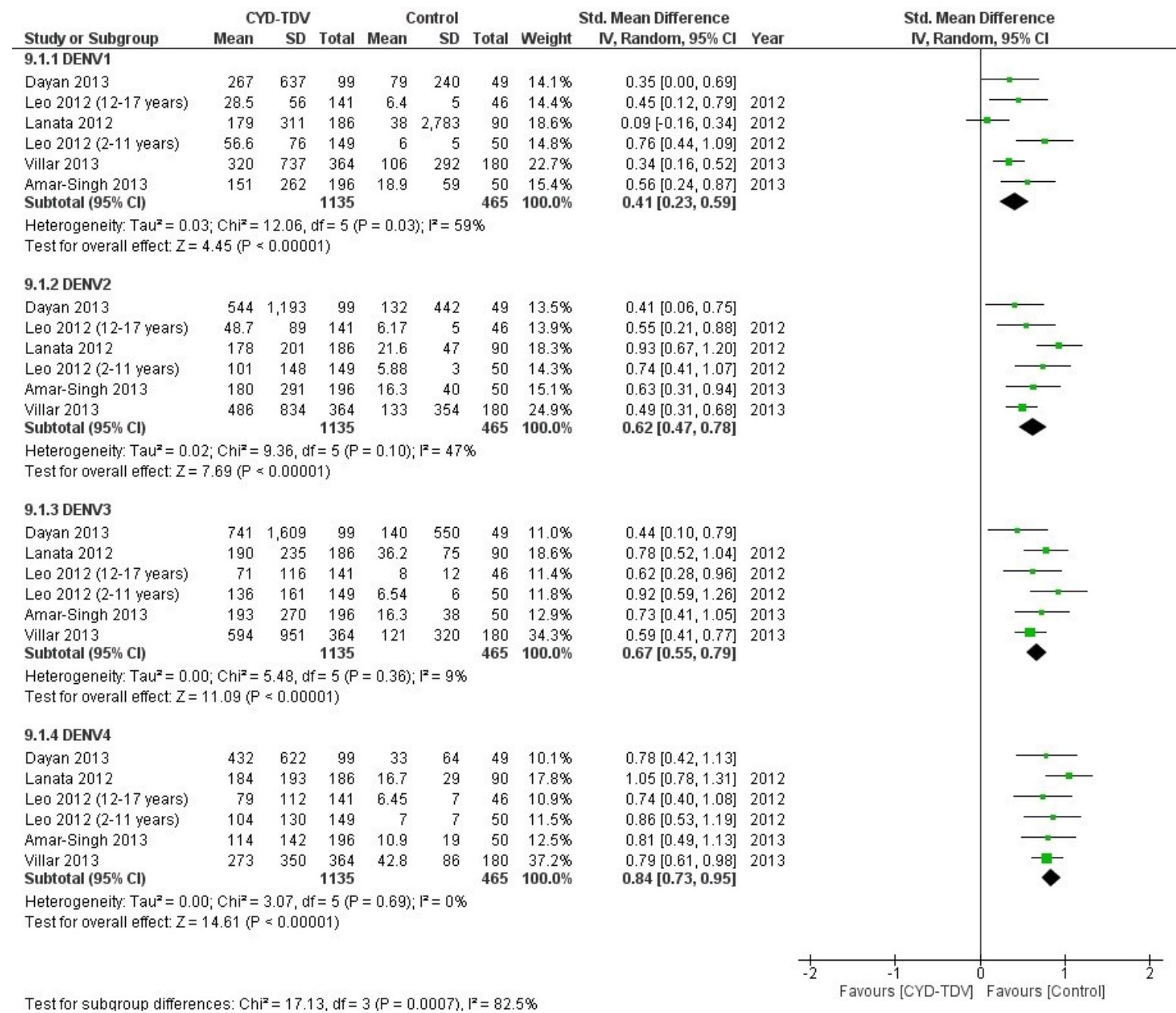


Figure 3B - Immunogenicity of CYD for adults

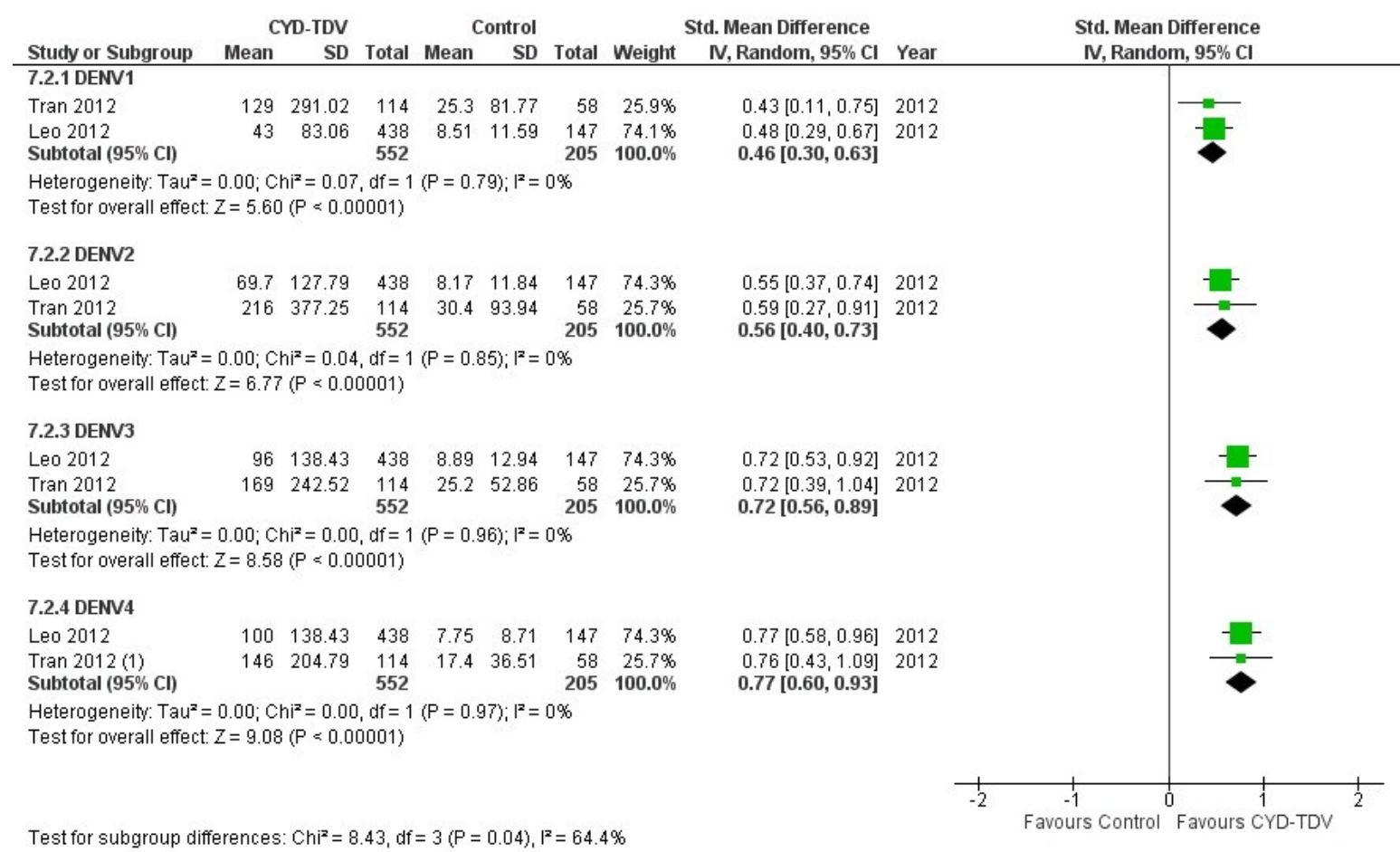

Efficacy

The pooled analysis of 27,355 person-years [30,31] showed a global risk ratio of $0.41(95 \% \mathrm{Cl} 0.35$, $0.48 ; I^{2}=0 \% ; p=0.52$ ). The global efficacy of $59 \%$ was found after 28 days after the third dose $\left(13^{\circ}\right.$ month) (per protocol analysis) (Figure 4). 
Figure 4 - Efficacy of CYD-TDV vaccines as per the protocols

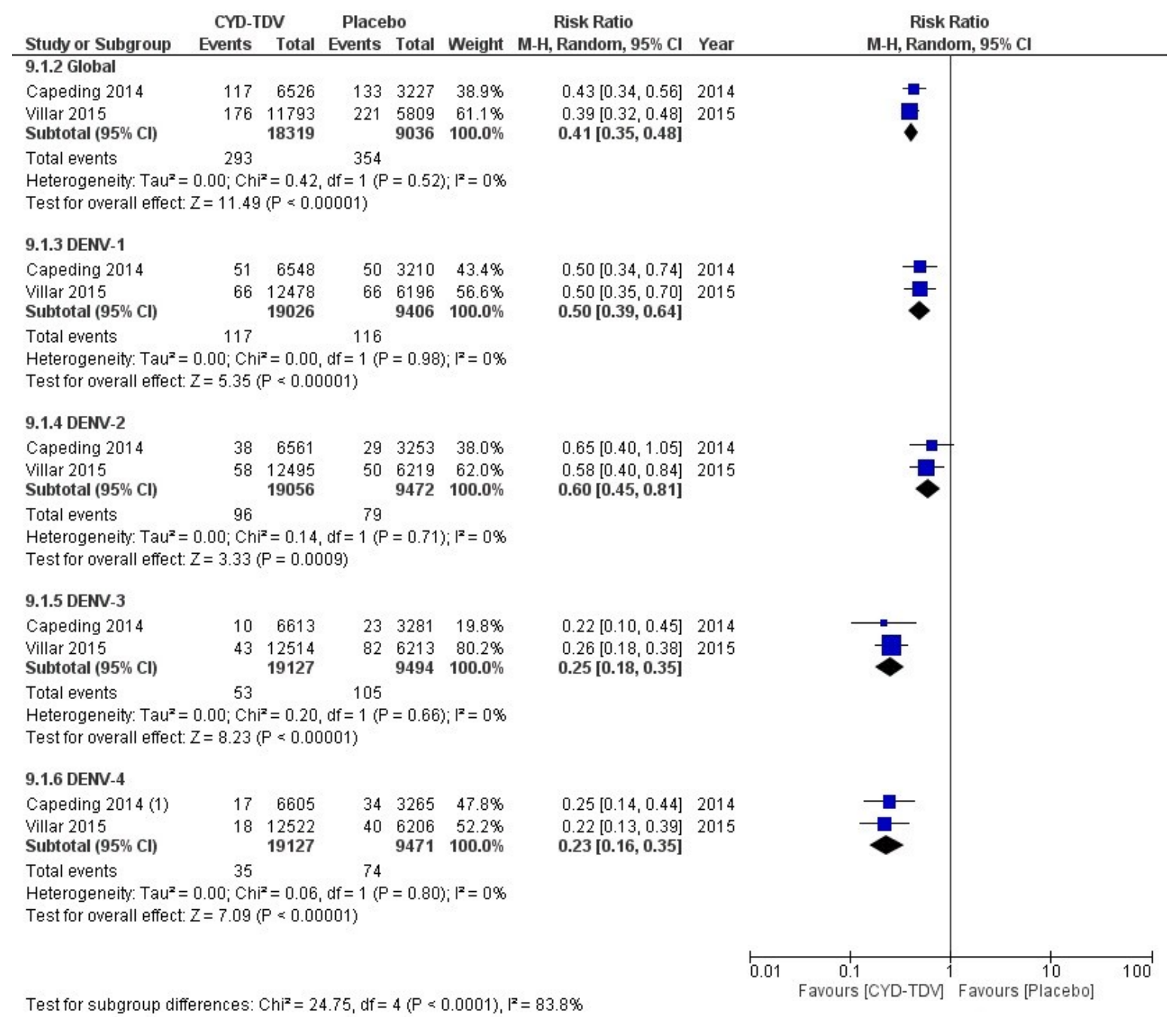

Intention to treat analysis revealed a global efficacy of $60 \%\left(R R=0.40 ; 95 \% \mathrm{Cl} 0.31,0.51 ; \mathrm{I}^{2}=79 \%\right.$; $\mathrm{p}=0.003$ ) and serotype stratified analysis showed that DENV4 and DENV2 presented the best and worst results, respectively $77 \%\left(R R=0.23 ; 95 \% \mathrm{Cl} 0.16,0.34 ; I^{2}=39 \% ; p=0.20\right)$ and $43 \%(R R=$ $0.57 ; 95 \% \mathrm{Cl} 0.44,0.74 ; \mathrm{I}^{2}=36 \% ; \mathrm{p}=0.21$ ) (Figure 5). 
Figure 5 - Efficacy CYD-TDV vaccine: intention to treat

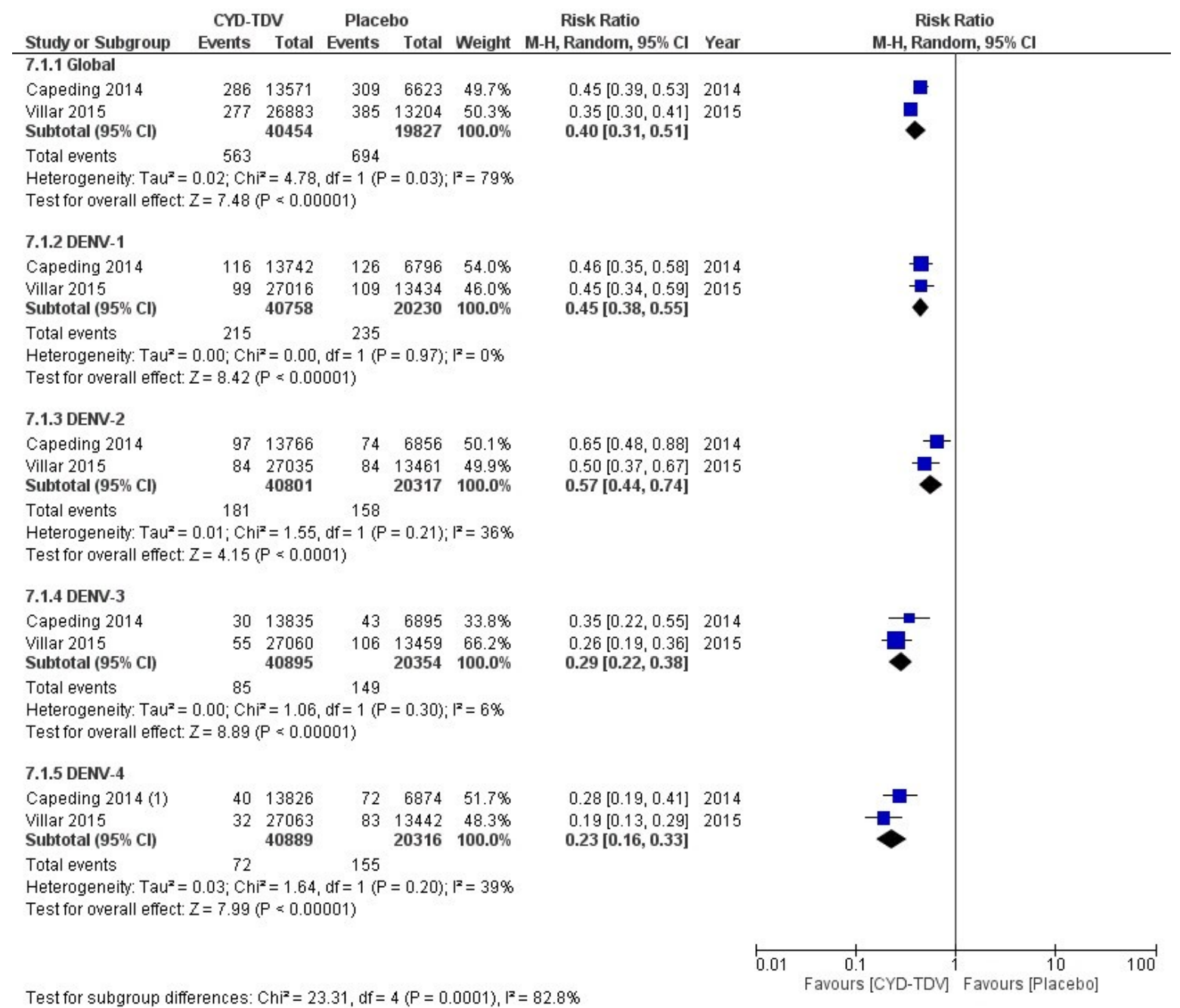

Vaccine efficacy in the cohort of DENV seropositive patients at baseline was $78 \%$ ( $R R=0.22$; $95 \% \mathrm{Cl} 0.14,0.35 ; \mathrm{I}^{2}=0 \% ; \mathrm{p}=0.36$ ). The meta-analysis result for seronegative patients at baseline was not statistically significant $\left(R R=0.62 ; 95 \% \mathrm{Cl} 0.37,1.03 ; l^{2}=0 \% ; p=0.82\right)$ (Figure 6$)$. 
Figure 6 - Efficacy/Flavivirus Seropositivity CYD-TDV vaccine

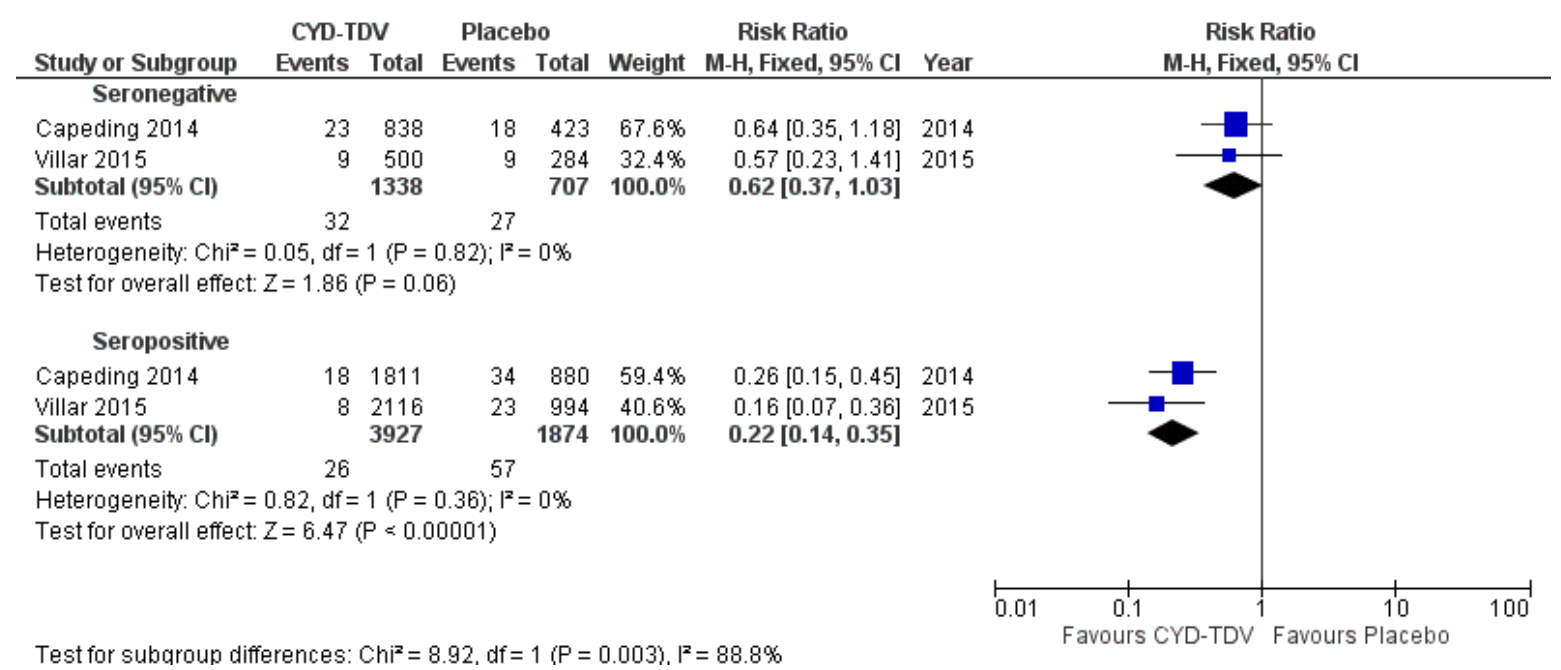

\section{Safety}

Injection site reactions seen with CYD-TDV were erythema $\left(R R=0.55 ; 95 \% C l 0.34,0.89 ; I^{2}=70 \%\right.$; $p=0.005)$ and swelling $\left(R R=0.33 ; 95 \% \mathrm{Cl} 0.17,0.64 ; l^{2}=67 \% ; p=0.009\right)$. No differences were detected between CYD-TDV and the control arm for the following outcomes: Pain (RR=0.71; $\left.95 \% \mathrm{Cl} 0.45,1.12 ; \mathrm{I}^{2}=91 \% ; \mathrm{p}<0.0001\right)$; fever $\left(\mathrm{RR}=1.20 ; 95 \% \mathrm{Cl} 0.78,1.83 ; \mathrm{l}^{2}=65 \% ; \mathrm{p}=0.02\right)$; malaise $\left(R R=1.19 ; 95 \% \mathrm{Cl} 0.98,1.45 ; \mathrm{I}^{2}=44 \% ; p=0.11\right)$; headache $(\mathrm{RR}=1.12 ; 95 \% \mathrm{Cl} 0.88,1.42$; $\left.\mathrm{I}^{2}=72 \% ; \mathrm{p}=0.003\right)$; myalgia $\left(\mathrm{RR}=0.85 ; 95 \% \mathrm{Cl} 0.63,1.16 ; \mathrm{I}^{2}=73 \% ; \mathrm{p}=0.05\right)$; and asthenia $(\mathrm{RR}=$ $\left.1.03 ; 95 \% \mathrm{Cl} 0.72,1.47 ; \mathrm{I}^{2}=57 \% ; \mathrm{p}=0.07\right)$. Serious adverse events occurred more frequently in the control group when compared to CYD-TDV $\left(R R=0.76 ; 95 \% \mathrm{Cl} 0.59,0.98 ; I^{2}=28 \% ; p=0.20\right)$. With exception of SAE, all other meta-analysis presented high heterogeneity (Table 2). 
$\underline{\text { Table } 2 \text { - Meta-analysis results of safety of CYD-TDV }}$

\begin{tabular}{|c|c|c|c|c|c|}
\hline Outcome/Group & $\begin{array}{c}\text { Study } \\
\text { number } \\
\text { (Table 1) }\end{array}$ & $\begin{array}{c}\mathrm{N} \\
\text { Vaccine } \\
\text { (cases/total } \\
\text { participants) }\end{array}$ & $\begin{array}{c}\mathrm{N} \\
\text { Control } \\
\text { (cases/total } \\
\text { participants) }\end{array}$ & Risk ratio (CI 95\%) & $\begin{array}{c}\text { Heterogeneity }\left(\mathrm{I}^{2} ;\right. \\
\text { p-value })\end{array}$ \\
\hline \multicolumn{6}{|l|}{ Pain } \\
\hline CYD-TDV & $23,25-29$ & $390 / 1,880$ & $248 / 739$ & $0.71(0.45-1.12)$ & $91 \% ;<0.00001$ \\
\hline \multicolumn{6}{|l|}{ Erythema } \\
\hline CYD-TDV & $23,25-29$ & $189 / 1880$ & $107 / 739$ & $0.55(0.34-0.89)$ & $70 \% ; 0.005$ \\
\hline \multicolumn{6}{|l|}{ Swelling } \\
\hline CYD-TDV & $23,25-29$ & $67 / 1,880$ & $73 / 739$ & $0.33(0.17-0.64)$ & $67 \% ; 0.009$ \\
\hline \multicolumn{6}{|l|}{ Fever } \\
\hline CYD-TDV & $23,25-28$ & $225 / 1,679$ & $78 / 688$ & $1.20(0.78-1.83)$ & $65 \% ; 0.02$ \\
\hline \multicolumn{6}{|l|}{ Malaise } \\
\hline CYD-TDV & $23,25-29$ & $700 / 1,906$ & $216 / 739$ & $1.19(0.98-1.45)$ & $44 \% ; 0.11$ \\
\hline \multicolumn{6}{|l|}{ Headache } \\
\hline CYD-TDV & $23,25-29$ & $764 / 1,880$ & $261 / 739$ & $1.12(0.88-1.42)$ & $72 \% ; 0.003$ \\
\hline \multicolumn{6}{|l|}{ Myalgia } \\
\hline CYD-TDV & $23,25-28$ & $561 / 1,681$ & $238 / 688$ & $0.85(0.63-1.16)$ & $73 \% ; 0.005$ \\
\hline \multicolumn{6}{|l|}{ Asthenia } \\
\hline CYD-TDV & $23,25-28$ & $300 / 1,561$ & $103 / 628$ & $1.03(0.72-1.47)$ & $57 \% ; 0.07$ \\
\hline \multicolumn{6}{|l|}{ Serious adverse event } \\
\hline CYD-TDV & $23-31$ & $595 / 25,309$ & $325 / 11,114$ & $0.76(0.59-0.98)$ & $28 \% ; 0.20$ \\
\hline
\end{tabular}

Subgroup and heterogeneity analysis

For global efficacy (intention to treat), the stratification based on age in the phase III studies [30, 31] led to decrease in $1^{2}$. The involvement of children under 9 years old, for example, in the study of Capeding et al (2014) demonstrated lower efficacy of CYD-TDV in this group. This can be explained by the heterogeneity between the studies $[30,31]$. When we sub stratified global efficacy results by age such as 2 to 5 years old: $34 \%(\mathrm{RR}=0.66 ; 95 \% \mathrm{Cl} 0.51,0.87), 6$ to 11 years old: $61 \%$ (RR= $\left.0.39 ; 95 \% \mathrm{Cl} 0.34,0.46 ; I^{2}=0 \% ; p=0.72\right)$ and $\geq 12$ years old: $69 \%\left(R R=0.31 ; 95 \% \mathrm{Cl} 0.25,0.38 ; I^{2}=\right.$ $0 \% ; p=0.34$ ), the heterogeneity was lower and the results continued to favor CYD-TDV for each age evaluated (Table S2).

Age is not only factor that can influence the heterogeneity of the efficacy findings in the various trials, seropositivity is another important aspect that needs to be considered [40,42]. As seen in figure 6 , it was possible to evaluate that the higher number of seropositivity participants contributed to better efficacy results.

\section{Discussion}

In accordance with the pooled analysis presented by Hadinegoro et al (2015) [43], meta-analysis results with 27,355 volunteers aged 2 to 16 years old from two phase III trials $[28,29]$ showed a moderate overall vaccine efficacy of $60 \%$ (intention to treat analysis). CYD-TDV ability to stimulate an immune response was measured by comparing the geometric mean titers of neutralizing antibodies against each dengue serotype of vaccines and controls. In 1,600 children and adolescents, the immunogenicity response revealed distinct profiles according to the DENV serotype, with DENV3 and DENV4 presenting best results [23-28]. The lower immunogenicity result for DENV1 was a prelude to the efficacy of $55 \%$ of CYD-TDV for this serotype. The efficacy against DENV2 was even lower (43\%) [30, 31]. These results coincided with the observation of the long- 
term safety analysis in which the majority of hospitalizations cases were due to DENV1 or DENV2 infections [43].

Data from two cluster studies conducted in Thailand suggested that higher levels of neutralizing antibodies are needed for protection against DENV2 in comparison to the other serotypes [51]. The explanation may lay in the fact that DENV2 strain can change in structure at body temperature $\left(37^{\circ}\right.$ C), suggesting that antibody binding may be affected, which may be associated with lower efficacy of CYD-TDV against DENV2 [52, 53]. It is known that secondary heterologous infections may increase the risk of severe disease [54]. Since CYD-TDV did not provide an adequate response, especially against DENV2, it is possible that after mass vaccination, a future DENV-2 epidemic may result in an increase of severe cases. This is the reason the WHO recommended long-term safety assessments of dengue vaccine candidates [55].

Meta-analysis of immunogenicity in adults was derived from two phase II trials with a total of 757 volunteers. The values of the mean difference showed that the vaccine showed best response against DENV4 and DENV 3, followed by DENV2 and DENV1, but unlike the situation in children and adolescents, the 95\% confidence intervals of the best response (against DENV4) and the worst response (DENV1) overlapped. In addition, Costa et al 2014 [6] also demonstrated the best immunogenicity results for DENV3 and DENV4, however in an analysis where children, adolescent and adult result were grouped. Accordingly, the moderate efficacy obtained in children and adolescents previously predicted from immunogenicity results may also be attained in adults.

According to the Office of Vaccines Research and Review in the U.S. Food and Drug Administration, immunogenicity assessment, as an auxiliary parameter for predicting efficacy, may be used for licensing purposes when a clinical efficacy study is not possible, such as when the burden of the disease is low, or when targeting a new population (age group) for which there is no comparator [56]. For the European Medicines Agency, pre-authorization efficacy trials may be waived when it is justifiable to "to gauge the likely efficacy of a vaccine by comparison of immunological responses with those seen in past studies of protective efficacy with similar vaccines", even when there is no correlate of protection [57]. Sanofi has filed for approval of the vaccine in 20 other countries where the dengue virus is most widespread and will file for approval in Europe in 2016, and in the U.S. in 2017 [58].

In both phase III trials seropositivity was evaluated at the time of study enrollment, and participants with PRNT50 >10 against one or more serotypes were considered seropositive baseline [30, 31], which was interpreted as evidence of previous exposure to at least 1 of the 4 dengue viruses [42]. When we stratified the efficacy results according to dengue seropositivity at baseline, we verified that CYD-TDV was effective in preventing dengue cases for seropositive volunteers ( $R R=0.22$ $95 \% \mathrm{Cl} 0.14 ; 0.35)$ but not for those seronegative at baseline, at least not in a conservative analysis (RR=0.62 95\%Cl 0.37; 1.03) [54].

This fact can be viewed in two opposite perspectives. On the positive side, anti-dengue vaccination will be adopted in dengue endemic areas with presumed high seropositivity status [55]. On the negative side, the fact that the vaccination wasn't effective for protection against dengue in seronegative volunteers indicates that the efficacy of CYD-TDV may be very different from country to country [30,31]. This highlights the need for seroprevalence studies capable of indicating the expected vaccine efficacy in each endemic country before any CYD-TDV pricing and funding considerations among health authorities within countries. The need for serosurveys was also stressed out by the World Health Organization (WHO), as they are considered the best method for selecting populations suitable for vaccination $[41,42]$.

The low efficacy in seronegative volunteers, along with the long vaccination scheme $(0,6$ and 12 months), may diminish the usefulness of this vaccine to travelers. According to GeoSentinel surveillance network, dengue is considered the leading cause of febrile illness among those with a specific diagnosis returning from every geographic region except sub-Saharan Africa and Central 
America. It is estimated that annually more than 53 million travelers from non-endemic areas arrived in the 21 most popular dengue endemic destinations between 2006 and 2007 [59]. In Japan, there have been 1007 reports of imported dengue cases between 2006 and 2014 from from Indonesia $(n=202)$, the Philippines $(n=230)$, Thailand $(n=160)$ and India $(n=152)[60]$.

In our meta-analysis, we did not find any statistical difference between CYD-TDV and control for occurrence of adverse events. Serious adverse events were more frequently seen in the control group $(\mathrm{RR}=0.76 ; 95 \% \mathrm{Cl} 0.59,0.98)$. A safety overview of phase I to III trials of CYD-TDV with volunteers between 2 to 60 years old showed that $0.3 \%$ of participants discontinued vaccination for safety reasons in the control and intervention groups, and the most common unsolicited adverse events were injection-site reactions, gastrointestinal disorders and infections [61]. According to the $\mathrm{WHO}$, an increased risk of hospitalized dengue was identified in the age group of 2 to 5 years old in the third year of follow up post dose 1. This fact, along with the lower efficacy observed in under 9 years-olds, led to a decision to exclude individuals aged 2-5 (and also those aged 6-8 years as a precautionary measure) from vaccination [42]. In addition, Hadinegoro et al (2015) demonstrated that hospitalization was more frequent in participants under the age of 9 years $(R R=1.58 ; 95 \% \mathrm{Cl}$ $0.83,3.02)$ than for participants 9 or more years of age $(\mathrm{RR}=0.50 ; 95 \% \mathrm{Cl} 0.29,0.86)$.

Hospitalization for severe dengue occurred in 18 of 22,177 in the vaccine group and 6 of the 11,089 in the control group [43].

The global vaccines market was estimated at around US\$32.05 billion in 2012 . The market witnessed growth rates of above $8 \%$ and is expected to reach US $\$ 84.44$ billion by 2022 [62, 63]. Specifically for dengue vaccine, it was estimated there would be 250 million dengue vaccines doses for Brazil and Colombia for the period 2015-2019, 38 million for routine doses, 148 million for catchup vaccination of under 15 year olds, and 62 million doses for vaccination of adults. In addition, the public sector cost would be US $\$ 2,400$ million over five years [64]. In Brazil, one state, Parana, decided to include CTD-TDV in the state immunization program. From the target population of 400,000 inhabitants (80\% coverage), only 190,000 took the first dose $[65,66]$.

The consortium created by WHO in 2015 estimated that CYD-TDV can be cost-effective in settings with intensity of transmission between $30-90 \%$, if the vaccine can be purchased and delivered cheaply enough. Vaccination will only be cost-effective using the public payer perspective if the total cost of fully vaccinating one person is below US $\$ 40$ [41]. Dengvaxia ${ }^{\circledR}$ was granted regulatory approval first in Mexico (12/09/2015), followed by the Philippines and in Brazil [34, 35, 36]. Until October 2016, eight more endemic countries (El Salvador, Costa Rica, Paraguay, Guatemala, Peru, Indonesia, Thailand and Singapore) gave Dengvaxia ${ }^{\circledR}$ regulatory approval [38]. Currently, the actual acquisition price in these countries is unknown. In Brazil, CYD-TDV has not been evaluated for incorporation into the national immunization program, however the National Health Surveillance Agency (ANVISA CMED) established a reference maximum price for government purchase, yielding a total of $\cup \$ 96.79$ [67] for the three dose scheme (World Bank for Purchase Power Parity (PPP), 2015: 1 US $\$=3.330 \mathrm{BRL}$ ).

In addition to CYD-TDV, another candidate vaccine, developed by the Butantan Institute (Brazil) in partnership with the United States National Institutes of Health, is going to be evaluated in a phase III clinical trial that has recently been registered at ClinicalTrials.gov [68].

A potential limitation of the present study is associated with the fact that the included studies were funded through pharmaceutical companies. It is known that studies of this financing type showed favorable results in response to the technologies [69, 70]. However, the quality of evidence and risk of bias demonstrated that the clinical trials included were high-quality studies to address such concerns. 


\section{Conclusions}

This systematic review summarized the results of high-quality studies and showed the safety of CYD-TDV. Denvaxia ${ }^{\circledR}$ showed global efficacy of $60 \%$ in volunteers under 16 years old and from the immunogenicity results in adults, we can expect satisfactory efficacy in this population after comercialization. However, there is a need to continue to evaluate the efficacy and safety of this vaccine. The numerous infections and occurrence of severe manifestations of the dengue virus in endemic regions reinforces the need for an effective and cost-effective vaccine to prevent this fever.

Our systematic review also emphasizes the need for pharmaceutical companies and researchers to comply with the technical rigor of the protocols for each phase of the clinical trials to support health authorities in decisions concerning the incorporation of such technologies into their health care systems and, above all, to enable the provision of a safe, effective and affordable vaccine to all to prevent dengue fever in the future.

\section{Five year view}

Dengue will continue to pose an important challenge to health systems in endemic areas since despite efforts to control the disease through vector control, the number of cases have continued to increase in recent years. This has not been helped by accelerated urbanization and low adhesion among the population to control measures, which is likely to continue. In addition, climate change (global warming) may continue to facilitate mosquitos' reproduction. Consequently, the availability of effective dengue vaccines, building on Dengvaxia ${ }^{\circledR}$ from Sanofi Pasteur, will continue to be welcomed. In addition, vaccines made available through partnerships with research institutes such as Butantan Institute (Brazil) and the United States National Institutes of Health. In the next 5 years, it is hoped that more studies and assessments of Dengvaxia $($ 's effectiveness, risks and benefits will be performed across all pertinent age groups. In addition, continued assessments of the effectiveness and safety of new vaccines will also be performed to aid decision making. The lack of a specific treatments and the difficulties for effectively controlling the vectors associated with dengue reinforce the need for vaccines with adequate safety and efficacy profiles as recommended by the WHO across key age groups.

\section{Acknowledgements:}

IPG received financial support from CAPES (Coordenação de Aperfeiçoamento de Pessoal de Nível Superior). The write-up was in part supported by a Newton Advanced Fellowship awarded to Professor Augusto Afonso Guerra Junior by the Academy of Medical Sciences, through the UK Government's Newton Fund programme.

\section{Conflict of interest statement:}

The authors declare that there are no conflicts of interest.

\section{Executive summary}

- Dengue virus is a serious global health problem with an estimated 3.97 billion people at risk for infection worldwide. Sanofi Pasteur's dengue vaccine (CYD-TDV) has already been granted regulatory approval in a number of countries for the prevention of dengue fever, and the numbers will grow

- This systematic review summarized the results of high-quality studies in terms of the efficacy and safety of CYD-TDV

- The Global Efficacy of CYD-TDV (Dengvaxia $\left.{ }^{\circledR}\right)-60 \%$ intention to treat $(\mathrm{RR}=0.40 ; 95 \% \mathrm{Cl} 0.31$, $\left.0.51 ; I^{2}=79 \% ; p=0.03\right)$ and $59 \%$ per protocol $\left(R R=0.41 ; 95 \% \mathrm{Cl} 0.35,0.48 ; I^{2}=0 \% ; p=0.52\right)$

- Efficacy by Serotype (Intention to treat) - DENV-1 (RR=0.45;95\%Cl $0.38,0.55 ; \mathrm{I}^{2}=0 \% ; \mathrm{p}=$ $0.97), \mathrm{DENV}-2\left(\mathrm{RR}=0.57 ; 95 \% \mathrm{Cl} 0.44,0.74 ; \mathrm{I}^{2}=36 \% ; \mathrm{p}=0.21\right), \mathrm{DENV}-3(\mathrm{RR}=0.29 ; 95 \% \mathrm{Cl}$ $\left.0.22,0.38 ; I^{2}=6 \% ; p=0.30\right)$ and DENV-4 (RR=0.23;95\%Cl $\left.0.16,0.33 ; I^{2}=39 \% ; p=0.20\right)$ 
- Global Efficacy/ Seropositivity: Seronegative: $38 \%\left(\left(\mathrm{RR}=0.62 ; 95 \% \mathrm{Cl} 0.37,1.03 ; \mathrm{I}^{2}=0 \% ; \mathrm{p}=\right.\right.$ $0.82)$ and Seropositivity: $78 \%\left(R R=0.22 ; 95 \% \mathrm{Cl} 0.14,0.35 ; l^{2}=0 \% ; p=0.36\right)$

- Safety - Local events: erythema $\left(R R=0.55 ; 95 \% C l 0.34,0.89 ; I^{2}=70 \% ; p=0.005\right)$ and swelling $\left(R R=0.33 ; 95 \% \mathrm{Cl} 0.17,0.64 ; l^{2}=67 \% ; p=0.009\right)$; Systemic Events - no statistical difference between the control and the intervention groups

- The efficacy and safety of dengue vaccines need to continue to be evaluated after commercialization.

- The numerous infections and occurrence of severe manifestations of the dengue virus in endemic regions reinforces the need for effective, safe and cost-effective vaccines across age groups to prevent this fever

\section{References \\ ${ }^{*}$ Of interest, ${ }^{* *}$ of special interest}

[1] Bhatt S, Gething PW, Brady OJ et al. The global distribution and burden of dengue. Nature. 25, 7-504 (2013).

[2] Brady OJ, Gething PW, Bhatt S et al. Refining the global spatial limits of dengue virus transmission by evidence-based consensus. PLoS Negl Trop Dis. 6:e1760 (2012).

[3] Thoisy B, Lacoste V, Germain A et al. Dengue Infection in Neotropical Forest Mammals. VectorBorne Zoonot. 9, 157-169 (2009).

[4] Simmons CP, Farrar JJ, Chau NV, Wills B. Current Concepts Dengue. N Engl J Med. 366, 14231432 (2012).

[5] Godoi IP, Taranto MFR, Lima WG et al. NS2B-NS3pro as a Molecular Target Drugs Development against Dengue. Biochemistry and Biotechnology Reports. 2, 16-30 (2004).

[6] Costa VG, Marques-Silva AG, Floriano VG, Moreli ML. Safety, immunogenicity and efficacy of a recombinant tetravalent dengue vaccine: A meta-analysis of randomized trials. Vaccine. 32, 48854892 (2014).

[7] Tomlinson SM, Malmstrom RD, Watowich SJ. New Approaches to Structure-Based Discovery of Dengue Protease Inhibitors. Infect Disord Drug Targets. 9, 1-17 (2009).

[8] Forshey BM, Stoddard ST, Halsey ES. Direct feeding on dengue patients yields new insights into human to mosquito dengue virus transmission. Future Virol. 8, 1145-1149 (2013).

[9] Yacoub, S, Mongkolsapaya, J, Screaton, G. Recent advances in understanding dengue. F1000Research. 78, 1-10 (2016).

[10] Reiter P. Aedes albopictus and the world trade in used tires, 1988-1995: the shape of things to come? J Am Mosq Control Assoc. 14, 83-94 (1998).

[11]Shepard DS, Undurraga EA, Halasa YA, Stanaway JD. The global economic burden of dengue: a systematic analysis. Lancet Infect Dis. 16, 935-41 (2016).

[12] Constenia D, Garcia C, Lefcourt N. Assessing the Economics of Dengue: Results from a Systematic Review of the Literature and Expert Survey. PharmacoEconomics. 33, 1107-1135 (2015).

[13] Webster, DP, Farrar, J, Rowland-Jones, S. Progress towards a dengue vaccine. Lancet Infect Dis. 9, 87-678 (2009).

[14] Durbin AP, Whitehead SS. Next-generation dengue vaccines: novel strategies currently under development. Viruses. 3, 800-14 (2011).

[15] Coulange BH, Benabdelmoumen G, Gergely A et al. Long term persistence of yellow fever neutralising antibodies in elderly persons. Bull Soc Pathol Exot. 104, 260-5 (2011).

[16] Kumar R, Tripathi P, Rizvi, A. Effectiveness of One Dose of SA 14-14-2 Vaccine against Japanese Encephalitis. N Engl J Med. 360, 1465-1466 (2009).

[17] Del Angel RM, Reyes-del VJ. Dengue vaccines: strongly sought but not a reality just yet. PLoS Pathog. 9, e1003551 (2013).

[18] Torresi J, Tapia-Conyer R, Margolis $\mathrm{H}$. Preparing for dengue vaccine introduction: recommendations from the 1st dengue v2V international meeting. PLoS Negl Trop Dis. 7, e2261 (2013). 
[19] Züst R, Dong H, Li XF et al. Rational design of a live attenuated dengue vaccine: 2-omethyltransferase mutants are highly attenuated and immunogenic in mice and macaques. PLoS Pathog. 9, e1003521 (2013).

[20] Huang CY, Kinney RM, Livengood JA et al. Genetic and phenotypic characterization of manufacturing seeds for a tetravalent dengue vaccine (DENVax). PLoS Negl Trop Dis. 7, e2243 (2013).

[21] Zhao H, Jiang T, Zhou XZ et al. Induction of neutralizing antibodies against four serotypes of dengue virusesby MixBiEDIII, a tetravalent dengue vaccine. PLoS One. 9, e86573 (2014).

[22] Dayan GH, Thakur M, Boaz M, Johnson C. Safety and immunogenicity of threetetravalent dengue vaccine formulations in healthy adults in the USA. Vaccine. 31, 54-5047 (2013).

[23] Dayan GH, Garbes P, Noriega $F$ et al. Immunogenicity and safety of a recombinant tetravalent dengue vaccinein children and adolescents ages 9-16 years in Brazil. Am J Trop Med Hyg. 89, 651058 (2013).

[24] Sabchareon A, Wallace D, Sirivichayakul C et al. Protective efficacy of the recombinant, liveattenuated,CYD tetravalent dengue vaccine in Thai schoolchildren: a randomized, con-trolled phase Ilb trial. Lancet. 380, 67-1559 (2012).

[25] Villar LA, Rivera-Medina DM, Arredondo-García JL et al. Safety and immunogenicity of a recombinant tetravalentdengue vaccine in 9-16 year olds. A randomized, controlled, phase II trial in Latin America. Pediatr Infect Dis J. 32, 9-1102 (2013).

[26] Leo YS, Wilder-Smith A, Archuleta $S$ et al. Immunogenicity and safety of recombinant tetravalent dengue vaccine (CYD-TDV) in individuals aged 2-45 years-Phase II randomized controlled trial in Singapore. Hum Vaccines Immunother. 8,71-1259 (2012).

[27] Tran NH, Luong CQ, Vu TQH et al. Safety and immuno-genicity of recombinant, live attenuated tetravalent dengue vaccine (CYD-TDV) in healthy Vietnamese adults and children. $J$ Vaccines Vaccin. 3, 1-7 (2012).

[28] Lanata CF, Andrade T, Gil Al et al. Immunogenicity and safety of tetravalent dengue vaccine in 2-11 year-oldspreviously vaccinated against yellow fever: randomized, controlled, phase llstudy in Piura, Peru. Vaccine. 30, 41-5935 (2012).

[29] Amar-Singh HSS, Koh MT, Tan KK et al. Safety and immunogenicity of a tetravalent dengue vaccine in healthy children aged 2-11 years in Malaysia: a randomized, placebo-controlled phase III study. Vaccine. 31, 21-5814 (2013).

**[30] Capeding MR, Tran NH, Hadinegoro SRS et al. Clinical efficacy and safety of a novel tetravalent dengue in healthy children in Asia: a phase 3 , randomized, observer-masked, placebocontrolled trial. The lancet. 384, 1358-1365 (2014)

One of the first phase III trials (efficacy) of a dengue vaccine candidate and included in our metaanalysis

${ }^{*}[31]$ Villar L, Dayan GH, Arredondo-García JL et al. Efficacy of a tetravalent Dengue Vaccine in Children in Latin America. New Engl J Med. 372, 113-123 (2015).

One of the first phase III trials (efficacy) of a dengue vaccine candidate and included in our metaanalysis

[32] Guy B, Saville M, Lang J et al. Development of Sanofi Pasteur tetravalent dengue vaccine. Rev Pan-Amaz Saude. 2, 51-64 (2011).

[33] Coller GBA, Clements DE. Dengue vaccines: progress and challenges. Curr. Opin Immunol. 23, 391-398 (2011).

[34] Sanofi Pasteur. Dengvaxia®, world's first dengue vaccine, approved in Mexico. 2015. Available at: (http://www.sanofipasteur.com/en/articles/dengvaxia-world-s-first-dengue-vaccine-approved-inmexico.aspx).

[35] Sanofi Pasteur. Sanofi Pasteur's dengue vaccine approved in the Philippines. 2015. Available at: (http://www.sanofipasteur.com/en/articles/sanofi-pasteur-dengue-vaccine-approved-in-thephilippines.aspx).

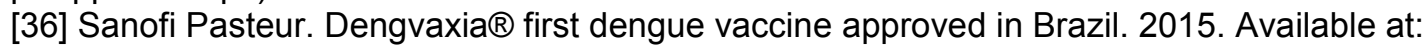
(http://www.sanofipasteur.com/en/articles/Dengvaxia-First-Dengue-Vaccine-Approved-inBrazil.aspx).

[37] Sanofi Pasteur. Sanofi Pasteur dengue vaccine approved in Costa Rica. 2016. Available at: (http://www.sanofipasteur.ca/node/49001). 
[38] Sanofi Pasteur. First Dengue Vaccine Approved in More than 10 Countries. 2016. Available at:http://www.sanofipasteur.com/en/Documents/PDF/PR/20161004_First_Dengue_Vaccine_Approv ed_in_More_than_10_Countries_EN.pdf).

[39] Dengue Vaccine Initiative. Dengue Vaccine Initiative Statement on SAGE Dengue Vaccine Recommendations. 2016. Available at (http://www.denguevaccines.org/sites/default/files/DVI\%20Statement\%20\%20SAGE\%20Recommendations\%20Dengue\%20Vaccines\%20April\%202016_0.pdf).

[40] European Medicines Agency. Committee for Human Medicinal Products - Guideline on immunogenicity assessment of biotechnology-derived Therapeutic proteins. 2007. Available at: (http://www.ema.europa.eu/docs/en_GB/document_library/Scientific_guideline/2009/09/WC500003 946.pdf).

${ }^{* *}[41]$ World Health Organization. Background paper on Dengue Vaccines. 2016. Available at (http://www.who.int/immunization/sage/meetings/2016/april/1 Background Paper Dengue Vaccin es 201603 17.pdf). The World Health Organization publications are important to dengue vaccine context

**[42] World Health Organization. Dengue Vaccine: WHO position paper - July 2016. Weekly Epidemiological Record, 30, 91, 349-364 (2016). Available at

(http://www.who.int/wer/2016/wer9130.pdf?ua=1). The World Health Organization publications that are important to dengue vaccine context

**[43] Hadinegoro SR, Arredondo-Garcia JL, Capeding MR et al. Efficay and Long-term safety of Dengue Vaccine in regions of endemic Disease. N Engl J Med. 13, 1195-1206 (2015). Important to complement our knowledge of the disease and of CYD-TDV

[44] Flashe S, Jit M, Rodrigues-Barraquer et al. Comparative Modelling of dengue vaccine public health impact (CMDVI). 2016. Available at:

(http://www.who.int/immunization/sage/meetings/2016/april/2_CMDVI_Report_FINAL.pdf).

[45] Ferguson NM, Rodríguez-Barraquer I, Dorigatti I. Benefits and risks of the Sanofi-Pasteur dengue vaccine: modeling optimal deployment. Science. 353 (2016).

*[46] Higgins JPT, Altman DG, Sterne JAC. Assessing risk of bias in included studies. In: Higgins JPT, Green S (editors). Cochrane Handbook for Systematic Reviews of Interventions Version 5.1.0 (updated March 2011). The Cochrane Collaboration, 2011. Available from www.cochranehandbook.org. Important reference source for conducting meta analyses

${ }^{*}$ [47] Liberati A, Altman DG, Tetzlaff J et al. The PRISMA statement for reporting systematic reviews and meta-analyses of studies that evaluate health care interventions: explanation and elaboration. PLoS Med. 7, 1-97 (2009). Important reference source for conducting meta analyses [48]Mansfield KL, Horton DL, Johnson N et al. Flavivirus-induced antibody cross-reactivity. J Gen Virol. 92, 2821-9 (2011).

[49] Deeks JJ, Higgins J, Altman DG. Chapter 9: Analysing data and undertaking meta-analyses. In: Higgins JPT, Green S (eds) Cochrane handbook for systematic reviews of interventions. 2010.

Version 5.1.0. www.cochrane-handbook.org

[50] Higgins JPT, Altman AD, Sterne JAC. Chapter 8: assessing risk of bias in included studies. In: Higgins JPT, Altman DG, Sterne JAC (eds) Cochrane handbook for systematic reviews of interventions. Version 5.1.0. 2012.www.cochrane-handbook.org

[51] Buddhari, D, Aldstadt, J, Endy, TP et al. Dengue Virus Neutralizing Antibody Levels Associated with Protection from Infection in Thai Cluster Studies Darunee Buddhari. PLoS Negl. Trop. Dis. 8, e3230 (2014)

[52] Guntur F, Thiam-Seng Ng, Victor AK et al. Structural Changes in Dengue Virus When Exposed to a Temperature of $37^{\circ} \mathrm{C}$. J. Virol. 13, 7585-7592 (2013).

[53] Guntur F, Kristie D.I, Thiam-Seng Ng et al. Cryo-EM structure of an antibody that neutralizes dengue virus type 2 by locking E protein dimers. Science. 6243, 88-90 (2015).

[54] Guy B, Jackson N. Dengue vaccine: hypotheses to understand CYD-TDV induced protection. $J$ Vector Borne Dis. 14, 45-54 (2016).

**[55] World Health Organization. Guidelines for the clinical evaluation of dengue vaccines in endemic areas - Immunization, Vaccines and Biologicals. 2008. Available at (http://whqlibdoc.who.int/hq/2008/WHO_IVB_08.12_eng.pdf). The World Health Organization publications that are important to dengue vaccine context 
[56] U.S. Food and Drug Administration. Office of Vaccines Research and Review Center for Biologics Evaluation and Research. Use of Immunogenicity Data to Assess

Vaccine Effectiveness. 2013. Available at:

(https://www.google.com.br/url?sa=t\&rct=j\&q=\&esrc=s\&source=web\&cd=1\&cad=rja\&uact $=8 \& v e d=0$ ahUKEwjJ8eemiZTQAhXFDpAKHeO_AjsQFggiMAA\&url=http\%3A\%2F\%2Fwww.fda.gov\%2Fdownl oads\%2FBiologicsBloodVaccines\%2FNewsEvents\%2FWorkshopsMeetingsConferences\%2FUCM3 38945.ppt\&usg=AFQjCNH191BGAMd4lpfWf9lwo3TS7Vn2qw).

[57] European Medicines Agency. Committee for Human Medicinal Products - Note for Guidance on the Clinical Evaluation of Vaccines. 2005. Available at:

(http://www.ema.europa.eu/docs/en_GB/document_library/Scientific_guideline/2009/09/WC500003 875.pdf).

[58] Roland D, Bisserbe N. Mexico Approves Sanofi's Dengue Vaccine But Pricing Questions

Remain. The Wall Street Journal. 2015. Available at (http://www.wsj.com/articles/mexico-approvessanofis-dengue-vaccine-but-pricing-questions-remain-1449676613).

[59] Leder K, Torresi J, Libman MD. GeoSentinel Surveillance of Illness in Returned Travelers, 2007- 2011. Ann Intern Med. 19, 456-468 (2013).

[60] Fukusumi M, Arashiro T, Arima Y et al. Dengue Sentinel Traveler Surveillance: Monthly and Yearly Notification Trends among Japanese Travelers, 2006-2014. PLoS Negl. Trop. Dis. 10, 1-14 (2016).

[61] Gailhardou S, Skipetrova A, Dayan, GH. Safety Overview of a Recombinant Live-Attenuated Tetravalent Dengue Vaccine: Pooled Analysis of Data from 18 Clinical Trials. PLoS Negl Trop Dis. 10, 1-25 (2015).

[62] Vaccine market by technology \& types, various classes \& indications - global forecasts to 2022. Research and Markets. 2013. Available at (www.researchandmarkets.com/research/x5nr7d/vaccine_market_by).

[63] Jadhav S, Gautam M, Gairola S. Role of vaccine manufacturers in developing countries towards global healthcare by providing quality vaccines at affordable prices. Clin Microbiol Infect. 20, 37-44 (2014).

[64] Dengue Vaccine Initiative. Planning for the introduction of dengue vaccines. 2011. Available at (http://www.denguevaccines.org/sites/default/files/ADPB-Brazil_11-Short.pdf).

[65] Secretaria de Saúde do Paraná. Manual de Normas e Procedimentos para vacinação Dengue. 2016. Available at

(http://www.saude.pr.gov.br/arquivos/File/VacinaDENGUE_protocolo.pdf).

[66] O DIARIO. Maringa vacinou 190 mil contra Dengue. Available at:

(http://maringa.odiario.com/parana/2016/09/parana-vacinou-190-mil-contra-a-dengue/2247982/).

[67] Brasil. Câmara de Regulação de Preços (CMED). 2016. Available at ( http://portal.anvisa.gov.br/documents/374947/2829072/LISTA_CONFORMIDADE_GOV_2016-1020.pdf/20b61fe1-f8a9-41ae-a55d-cb8613953dd8).

**[68] BRASIL. Anvisa autoriza Instituto Butantan a iniciar Ensaio Clínico fase 3 da vacina contra dengue. 2015. Available at

(http://portal.anvisa.gov.br/wps/content/anvisa+portal/anvisa/sala+de+imprensa/menu++noticias+anos/2015/anvisa+autoriza+instituto+butantan+a+iniciar+ensaio+clinico+fase+3+da+vaci na+contra+dengue). This reference indicates that the vaccine developed by Butantan Institute (Brazil) gained approval for a phase III trial, which will probably lead to licensing of the vaccine in Brazil in the coming years

[69] Bero L, Oostvogel F, Bachetti P, Lee K. Factors assoated with findings of published trials of drug-drugs comparisons:why some stations appear more efficacious than others. Plos Med 2007; 4(6), e184.

[70] Lexchini J, Bero LA, Djulbegovic B, Clark O. Pharmaceutical Industry sponsorship and research outcome and quality: systematic review. BMJ 2003; 1167(326): 1167-1170. 